\title{
MAKING SENSE OF THE 2016 WATER CRISIS IN SAN ANDRES, A COLOMBIAN CARIBBEAN ISLAND
}

\author{
Carolina Velasquez*
}

\begin{abstract}
In October 2015, the Colombian Institute of Hydrology, Meteorology and Environmental Studies (IDEAM) declared that the El Niño In October 2015, the Colombian Institute of Hydrology, Meteorology and Environmental Studies (IDEAM) declared that the EI Niño affected areas was San Andres, a touristic drought-prone Colombian Caribbean island. On April 2, 2016, there were 11 road protests spread throughout the south-center of the island where the Raizales, an ethnic-minority group, and people from poor neighborhoods burned tires, blocked streets, and held up signs saying, "We need water." That was the official beginning of the water crisis, which had by then affected 14,000 people. On April 15, the local government, for the first time in its history, declared a State of Public Calamity, attributing the causes of the lack of water to the El Niño phenomenon. The government established the El Niño phenomenon as the only trigger of the crisis, but the ways in which the community framed and understood the water crisis were overlooked. Acknowledging the importance of the community voice, this research analyzes the way people were affected and public officials made sense of the water crisis. Thirty-four semi-structured interviews were conducted in August, 2016 with a variety of stakeholders. The results show that officials were more inclined to frame the water crisis as a problem triggered mainly by technical and natural issues. On the community side, people framed the water crisis as a problem where social issues like justice, in relation to tourism, predominated. This study helps to expose and understand the complexity of the San Andres water crisis and ultimately contributes to the prevention of repeated or more severe crises.
\end{abstract}

Keywords: Water crisis; San Andres island; Drought.

\section{INTERPRETANDO A CRISE DE ÁGUA DE 2016 EM SAN ANDRES, UMA ILHA DAS CARAÍBAS COLOMBIANA}

Em outubro de 2015, o Instituto de Hidrologia, Meteorologia e Estudos Ambientais (IDEAM) afirmou que El Niño tinham atingido níveis graves e em 13 de Julho de 2016 as condições meteorológicas tinha voltado ao normal. Uma das áreas afetadas foi a ilha de San Andrés, na Colômbia; um destino turístico vulnerável à seca. Em 2 de abril de 2016 houve 11 protestos distribuídos em áreas do centro e partes superiores da ilha, onde a população nativa ilhéu, o grupo étnico na ilha, e pessoas de baixa renda queimaram pneus e expressou "precisamos de água". Os protestos foram o início da crise hídrica que afetou mais de 14 mil pessoas. Em 15 de abril, 0 governo local declarou pela primeira vez na história da ilha a calamidade pública causada, principalmente, pelo fenômeno El Niño. A voz das pessoas afetadas na compreensão das causas da crise não foi levada em conta. Com isso em mente, esta pesquisa explora e analisa o modo como a comunidade e as instituições entendem a crise hídrica. 34 entrevistas semiestruturadas foram realizadas em agosto de 2016. Os resultados mostram que os funcionários das instituições tendem a definir a crise como um problema causado por fatores naturais e técnicos. As pessoas afetadas pela crise, ao contrário, definiram a crise como um problema gerado pelo social, especialmente pela injustiça da água. Esta pesquisa ajuda a entender a complexidade da crise da água na ilha e, em última análise, contribui para a prevenção de futuras crises.

Palabras clave: Crisis del agua; Isla de San Andrés; Sequía.

\section{INTERPRETANDO A LA CRISIS DEL AGUA 2016 EN SAN ANDRES, UNA ISLA DEL CARIBE DE COLOMBIA}

En Octubre del 2015 el Instituto de Hidrología, Meteorología y Estudios Ambientales (IDEAM) declaro que el Fenómeno del Niño había alcanzado niveles severos y que en julio 13 de 2016 las condiciones climáticas habían vuelto a la normalidad. Una de las áreas afectadas fue la isla de San Andrés, Colombia; un destino turístico vulnerable a las sequias. El 2 de abril de 2016 hubo 11 protestas distribuidas en las zonas céntricas y partes altas de la isla, donde la población Raizal, grupo étnico de la isla, y personas de bajos recursos quemaron llantas y manifestaban "necesitamos agua." Las protestas fueron el inicio de la crisis del agua que afecto a más de 14 mil personas. En abril 15 el gobierno local declaro por primera vez en la historia de la isla la calamidad pública a causa, principalmente, del fenómeno del Niño. La voz de las personas afectadas en la comprensión de las causas de la crisis no fue tenida en cuenta. Teniendo en cuenta esto, la presente investigación explora y analiza la forma en que la comunidad y las instituciones entienden la crisis del agua. Se realizaron 34 entrevistas semi-estructuradas en Agosto de 2016. Los resultados muestran que los oficiales de las instituciones están inclinados a definir la crisis como un problema causado por factores naturales y técnicos. Las personas afectadas por la crisis, por el contrario, definieron la crisis como un problema generado desde lo social, especialmente por la injusticia del agua en relación con el turismo. Esta investigación contribuye a entender la complejidad de la crisis del agua en la isla y ultimadamente aporta en la prevención de futuras crisis.

Palabras clave: Crisis del agua; Isla de San Andrés; Sequía.

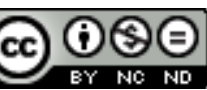

Licenciada por Creative Common Atribuição Não Comercial / Sem Derivações/ 4.0 / Internacional
* PhD Candidate in Disaster Science \& Management and currently a research assistant in the Disaster Research Center at University of Delaware. She holds a master's degree in Caribbean Studies, from the National University of Colombia. Her master thesis was related with risk in the agricultural production system where she focuses in vulnerability studies in hurricanes. She has both presented at conferences and worked with think tanks on tourism, risk management environmental urban planning and climate change. Address: Disaster Research Center, School of Public Policy and Administration (SPPA), University of Delaware. 84 Academy St, Newark, DE 19716, EUA. [ csvelas@udel.edu ] 


\section{INTRODUCTION}

Problems of access to water in the Caribbean region are a result of the interaction of diverse aspects like mass tourism, poor governance in water management, social inequities, and the prohibitive cost of accessing water from formal and informal water companies, all painting a picture of increasing vulnerability to droughts in the Caribbean region.

Fresh water is a critical resource for Caribbean islands and has been recognized as one of the scarcest resources for the tourism industry (UNWTO, 2003). Regarding that tourism is the main economic activity in this region (since 2013 declared as a Sustainable Tourism Zone), as tourism grows in a sustainable way from 4\% to 7\% per year (Mantilla et. al, 2015).

According to the Fourth Assessment Report of the Intergovernmental Panel on Climate Change (IPPC), "small islands are vulnerable, especially Caribbean islands that are likely to experience increase in water stress and the occurrence of more frequent and more severe droughts (Tompkins, 2005; Cashman, 2013)." Vulnerable islands under water scarcity or under a prolonged drought episode can suffer from deepening water crises.

Disaster researchers have documented that crisis and disasters are social processes having their foundation in social, economic, cultural, and political structures (Bleikei, et al., 1994; Fothergill, et al., 1999). Hart, Boin, and Kuipers, (2017: 35) argue that is

"people's frames of reference, experience, memory, values, and interests that determine their perceptions of the crisis; and this meaning making process results from an intricate interaction between events, individual perceptions, political reactions, and government perception."

With that in mind, understanding crisis is connected to different perceptions and attached to a participatory process in order to appropriately manage the crisis. However, as time has passed, there has been only a partial perspective where practitioners and researchers mainly focused on hazard assessment but not including people's voices.

The problem then presents itself as how to address the needs and concerns of all members of a society in a socially just and ethical manner (Vojinovic and Abbott, 2012). Nancarrow et al. (2002) explain that usually water managers assume that the water system implemented is accepted by consumers, due to the necessity of specialized knowledge, and thus they do not embrace any participatory process. In terms of finding solutions to water crisis, the decision-making process typically neglects the community voice and it is these voices that are needed to fully understand the complexity of water problems and proposed public water policy recommendations. Therefore, a shift from pure hazard analysis and technological answers to a socio -political understanding, where assessments with a bottom-to-top approach is crucial and beneficial for ensuring community involvement in decision-making processes.

San Andres, Colombia, is a small Caribbean island that is suffering from a water scarcity. It is a touristic destination struggling with tourism's water demands. It is visited annually by more than 1,000,000 tourists (Howard, 2015). It is located in the southwest of the Caribbean Sea, about 800 kilometers to the mainland Colombian Caribbean coast. San Andres has historically been a drought-prone region and has suffered problems in water management during more than 40 years.

The current water supply system in the island has come, since 2013, under increased stress due to the Niño phenomenon, tourism, and growing population, all resulting in a water crisis in 2016. The crisis affected people differently, people situated in the north and part of the southeast-where commerce and tourism are located-did not display several problems with water access, and people located in the hilly part, and the south and center of the island suffered the most. The water crisis exposed the risk to some individuals and also exposed the social factors that lead to differential vulnerability (Wisner et al., 2005).

Studies on water resources on San Andres island has been produced by a few authors, a historical reference about the state of the water resource in the island is made by Robinson (1974) who described the social impacts of the Free Port Regime in the islanders live, she pointed out that the water services were extremely deficient, and she named some obstacles in the access to water in the island: the high cost of the water; second, the failure of the installations of water pipelines; third, the lack of sewerage that affected the quality of the water in the aqueduct.

Aguado (2010) recounts and analyzes the environmental history of water in the island; Arboleda, (2010) made an analysis of the state of potable water and sanitation in the island. Research references about the nexus of water and tourism are still negligible, only some authors have discussed this topic with different nuances, Mattos (2004); Guerrero (2015); James (2013; 2015) and Barrios (2015), and despite the fact that San Andres is a drought prone area, to date there are no studies about water crises and droughts in the island.

Regarding the above-mentioned, this research rather than narrowly analyzing water problems in islands as simple technical problems or focus on 
touristic consumption or only on drought as the main natural hazard cause for water problems. In contrast, it moves beyond the technocratic view to the roots of many of our problems nowadays and emphasizes the way individuals make sense of a common problem, and in particular the different ways people and public officials made sense of the water crisis happened in San Andres in 2016.

This will help to understand and give insights about the configuration of the crisis in the past, today, and for eventual crises in the future. This research takes a qualitative approach exploring how people who live or work on San Andres Island perceive and talk about water access and availability, with special emphasis on the 2016 water crisis. Thirty-four semistructured interviews were conducted in August, 2016 with a range of community stakeholders, including government officials, water utility companies, private company personnel, and residents in water crisis affected communities.

The following paragraphs explained the theoretical framework and the main concepts used, San Andres' socio-economic, political and ecological context, and the water crisis, then, it presents and analyzes the people and public official's voices and closes with conclusions and recommendations. This paper is an initial step towards understanding the complexity of water crisis in small Caribbean islands and the difficulty in addressing such crisis when the variety of stakeholder's perceptions are taken into consideration. It hopes that this research contributes to discovering different ways to comprehend and manage water crises in tourist areas.

\section{DROUGHT AND WATER CRISES}

Climate change has brought new challenge, especially for small islands. Scientific evidence shows that climate change exacerbates hydro-meteorological hazards and development problems, generating new modern crises.

The complex impacts of this change can be seen when ocean water warms and expands, glaciers and ice sheets melt, and sea levels rise. Rising sea levels lead to more saltwater intrusion into aquifers that in turn reduce the supply of fresh water in the islands. Warmer waters also fuel stronger hurricanes, causing severe physical and economic damage, and changes in precipitation patterns affect the occurrence of drought (Bueno, 2008).

Climate change significantly affects both atmospheric and ocean conditions, so, changes in the El Niño phenomenon are likely to be expected; however precise predictions about the variability of these factors are difficult to make.
The dynamic conditions of El Niño cause large changes in the amount of precipitation in different parts of the Caribbean region. The climate effects of El Niño are being associated with drought in the Caribbean and Central America. For example, the last quarter of 2009 through the first quarter of 2010 was a period of extreme water shortage in the Caribbean due to the effects of the El Niño-Southern Oscillation (ENSO) inter-annual variability (Gamble and Curtis, 2008). This drought showed the Caribbean vulnerability and the weaknesses of their water production and distribution systems.

In the same way, the most recent Niño, which held sway in 2015 and 2016, was one of the strongest on record. Droughts have triggered water crises in some islands like Grenada and Petite Martinique (Peters, 2015).

In the Caribbean region drought is already causing severe and cumulative impacts that makes them more severe every year, progressively impacting the community and economic sectors, like tourism and agriculture. For example, Jamaica has been frequently impacted by drought. During 1997 and 1998 the island experienced a 17-month drought that resulted in US $\$ 4.7 \mathrm{M}$ damage to the agriculture sector (Mills, 2000).

Later, in 2004-2005, a seven-month drought, accompanied by a number of bush fires, caused tremendous damage in agriculture and tourism that resulted from the combination of simultaneous hurricanes and drought (Campbell, Barker, and McGregor, 2011).

Tourism is a water intensive industry and any reduction of water supply can severe affect it. The use of water by tourists far exceeds the local's consumption, while a local drinks 150 Lt/day, a tourist drinks almost double, 293 Lt/day (Coralina, 2015). According to Peters (2015), the highest use of water in tourism is during the Caribbean dry season when water production from surface and ground water sources are at their lowest.

However, as agriculture and tourism are affected by the absence of water they can also create water scarcity conditions (Gössling, 2001). The relationship between tourism and crisis has been studied from various perspectives: 1) Tourism can increase vulnerability and generate crisis conditions, 2) crisis or disasters can impact severely the tourism industry, a highly susceptible economy to external factors, and 3) tourism can help to reduce touristic destination vulnerabilities and provide development opportunities. Generally, studies have inclined to analyze how disasters can impact severely the tourism industry, and what management strategies are necessary to protect the touristic destination. For instance, Durieux, Antunes, and Amaral (2010) studied the adequacy of 
the post-disaster strategies implemented by the city administration in the city of Blumenau after the flood of November 2008; Rocha and Mateddi (2016) analyzed the effects of disasters on tourism, focusing on the tourist destination Costa Verde e Mar, at Santa Catarina. In this regard, there is a lack of studies focusing on the way tourism industry create vulnerable conditions.

Social factors such as water overexploitation, water mismanagement, inadequate tourism and agriculture public policies, and land degradation can create drought conditions taking the naturalness out of the hazard (Kelman, 2015).

The community become more prone to face and more fragile to cope with droughts (Wilhite, 2000). In this context, several authors warn that more efforts have been made on studying and quantifying drought as a natural hazard than in exploring societal vulnerability in relation to drought (Downing and Bakker 2000; Wilhite 2002; Gonzalez et al., 2016).

The causes and consequences of drought are difficult to identify. Precipitation deficiency is commonly recognized as the trigger and its impacts as its characteristic, but currently droughts are more humancaused than precipitation-caused (Kelman, 2015).

Drought develops over time, it has various durations; for instance, it can happen for one season, for several years or several decades (Trnka et al., 2017). Indeed, the water shortage in the soil, reservoirs, rivers, aquifers, acts as an indicators of the occurrence of the hazard.

In a brief review, various researchers have been contributing to definitions, analysis, and description of drought's causes and impacts (Wilhite, Hayes, Glantz; Paulo and Pereira, 2006, Namias, 1982; Griggs 2014; Massinde, 1995). Studies focusing in plans, program, and policies for drought management (Willhite et al., 2000; Botteril and Hayes, 2012; Deister 2015).

Some researchers are looking to understand widespread perceptions and attitudes about drought (Nounderberg, Wilhite and Hayes, 2008). Lastly, investigations about drought and crisis in small islands are difficult to find; studies about drought are more related to technical and natural approaches and, on the contrary, studies about crisis are more inclined to social, organizational, and political sciences.

In the Caribbean region water availability is reaching a crisis point and this become more apparent during the dry season, which also correlates with the tourist high season (Cole, 2015). Gössling, (2001) argues that small islands such as Bermuda, the Bahamas, the Cayman Islands and several Pacific atolls have aquifers which are now over-exploited or approach to crisis where water conflicts are more frequent; certainly water crises are sociopolitical.
They are triggered by natural (droughts) and social forces (malfunctions of a society's sociotechnical and political administrative systems), which interact over time to produce a threat to core values and lifesustaining systems of a community (Boin, A., McConnell, A. \& Hart, P. 2008).

According to Quarantelly (1993) and Stern (2009, 2013) every crisis has its own unique features and causes. Overall, crises are social processes having their foundation in economic, cultural, and political structures (Bleikei et al., 1994; Fothergill, et al., 1999). Quarantelly (1993) states that all crises have three inter-related features: they are a threat, are unexpected, and lead to an urgent situation.

Stern (2009), instead of using unexpected, sudden or surprising, emphasizes uncertainty as a crisis feature regarding the nature of the threat. Stern (2009) states that threat, uncertainty, and urgency provide a means of preparing to act. Crisis embraces the serious threat but also the exit door, "the situation may look bad, but it is not hopeless (Boin, Hart, and Kuipers, 2017)."

Current crises, called by Boint and Hart (2003) modern crises, are the product of several modernization processes including technological advances, deregulation, and globalization, which makes them more complex and no longer confined to their site of origin. They recommend "to treat crises as extended periods of high threat, high uncertainty, and high politics that disrupt a wide range of social, political, and organizational processes" (p. 545).

This crisis approach does not focus exclusively on categorizing events in "natural" or "man-made" frames. It is the perception of threat that matters. It recognizes that a crisis is the product of shared perception (Boin, Hart, and Kuipers, 2017). It highlights that people do not always agree whether a crisis exists, and this creates room, for example, for politicians, stakeholders, media, and citizens to actively try to make sense of and manage the crisis.

Perceptions of crisis are likely to vary among stakeholders. Actors may adopt fundamentally different postures, according to their experience, levels of vulnerability and resilience, different values, positions and responsibilities (Boin, Hart, and McConnell, 2014). The social construction of the crisis can vary among communities and these different ways to perceive it might lead to different solutions (Velasquez, 2016). Therefore, it is argued that crisis is political in nature and perception studies are fundamental to the understanding of any crisis.

Modern water crises, for example, involve not only natural but also important political and economic forces; worldwide water companies with new technologies like desalinization plants are becoming 
the owners of the water resources, influencing the allocation of water resources, thus raising issues of water equity.

A water crisis has characteristics of a slow onset process, including the convergence of factors, and the combination of multiple events. According to Austin, Grosso, and O'Neil, (2017:5), crises

"occur gradually over time when diverse factors converge and turn into a crisis situation, it takes a long time to produce emergency conditions and do not emerge from a single, distinct event".

Trottier (2008) maintains that crisis mainly has its roots in social factors; "water is short only when social actors have decided it." He argues that a drought may be consider as a natural phenomenon and can trigger a crisis, but a water crisis is necessarily a hybrid process.

Generally, there has been little inclusion of people affected in the comprehension and solutions of a crisis, exacerbating the impacts or provoking the occurrence of new crises. This problem has been viewed as a response to the failures of top-down development models that fails to engage with the needs of vulnerable groups of society (Boyd et al., 2009).

Heltberg, Siegel, and Jorgesen, (2010) explain that a key element of good governance is giving voice to the community and especially to the marginalize groups to ensure their representation. With that in mind, it is critical to take into account different perceptions (community and organizations) of the features of the crisis; for example, is it defined as a static event, an ongoing process, a hybrid phenomenon with natural (hazards) and social (vulnerability) components, or an isolated or global phenomenon?

Studying water crises must include these multiple ingredients in order to find the right problem and formulate and implement the right solution. Regarding crisis complexity in its relation with water and tourism, integral studies are not easy to find, some tend to investigate through the lens of social approaches, but in the case of water management, they apply a technocratic view.

This suggests that an important gap to fill is the lack of water crisis studies having a more comprehensive view. Also, much work remains to be done on the understanding of crisis dynamics. If crises cannot be prevented, we must learn, through a participatory process, to recognize them in time.

\section{SAN ANDRES ISLAND IN CRISIS}

The Archipelago of San Andres, Providence and Santa Catalina (Colombia) is a group of small islands located in the Caribbean Sea, between $12^{\circ}$ and $16^{\circ} \mathrm{N}$ and $78^{\circ}$ and $82^{\circ} \mathrm{W}$. It is located in the southwest of the Caribbean Sea, about 800 kilometers to the north-west of the Colombian Caribbean coast. The capital is San Andres Island. It has a surface area of $27 \mathrm{~km} 2$. It has the smallest land area and a highest population density (approx. 2573hab $/ \mathrm{km} 2$ ) of any Colombian Department (PDGR, 2013).

San Andres Island is both a Department (province) and a Municipality, as a result, it has special regulations that allow it to be flexible with political and economic policies. As a small island, it shares certain inherent vulnerabilities and characteristics with other small islands.

These characteristics include: "small size, vulnerability to climate change, isolation within the Caribbean, scarcity of natural resources mainly fresh water, a location susceptible to the hurricane path, the presence of endangered species, and limited economic, institutional, and human resource capacity (Belmar, McNamara, and Morrison, 2016).

The society of San Andres have close family relationship where people know each other; strong cultural heritage, sense of identity, sense of place; a past of dealing with social, political, and environmental changes (Kelman, 2010); and a persistent conflict with the central government in Bogota, Colombia.

The Archipelago has a traditional culture that is defined by its Anglo-Puritan/African heritage, Protestant religious tradition, and English mother tongue, which now enjoys the legal protection granted to ethnic minorities by Colombia's Constitution of 1991. The majority of this group is located in the hills and the south of the island.

Since 1953 there has been very rapid population growth. For example, in 1951 there were 5,675 inhabitants and by 1964 there was an increase to 16,731 inhabitants, and this process continued and by 1985 there were 43,685 inhabitants (CORALINA, 2008). According to the projections of the DANEplanning Department (2014), currently the population of Archipelago exceeds 75,000 inhabitants.

As these numbers have increased, the indigenous ethnic group has become a minority in its own ancestral territory, representing only $39.4 \%$ of the population (James, 2015). Currently, different cultural groups cohabit the island from different parts of Colombia including Medellin, Cartagena, Barranquilla, and also from the Middle East, like Turkey and Lebanon.

UNESCO, in November, 2000, declared the islands a protected nature biosphere reserve, called Seaflower. Its nomination fulfilled a series of specific requirements including high biodiversity, possibilities for testing and demonstration of sustainable development with community participation, sufficient 
importance for conservation, and administrative capacity to implement a zoning and management plan.

According to Mow (2007), this designation turned Seaflower into the world's largest Biosphere Reserve and signified a transformation in the environmental management of the Archipelago. However, contrary to the intention to reduce environmental problems in the Archipelago, after 16 years of implementation of the BR program the problems have been magnified in quantity and complexity.

The Seaflower biosphere reserve is suffering from multiple problems, including: poor solid waste management, scarcity of fresh water, inadequate liquid waste collection, treatment, and disposal, deforestation, land invasions in environmentally sensitive areas, land use change, and loss of habitats (BR Report, 2005).

Tourism is posing a strong pressure on the island, which is visited annually by more than $1,000,000$ tourists (Howard, 2015). There are global forces incentivizing the growth of this activity where international and national tourist agencies are becoming more prevalent. The increasing number of residents and tourists is putting pressure on water resources, producing over-exploitation and lowering of the groundwater table in aquifers.

The water that currently supports life on the island comes from three main sources: precipitation, groundwater, and desalinization, with precipitation and groundwater being the primary sources. After more than 40 years of sociotechnical difficulties in water management, in 2004, San Andres' government selected the private company Proactiva Aguas del Archipiélago S.A. E.S.P (currently Veolia) as the operator to provide water supply, aqueduct, and sewer services. The local government and Veolia signed a contract on September 8, 2005 for a term of 15 years (PDA, 2010). After this, the contract became the central core of water policy in the island.

The private water company has two methods to produce fresh water: a water softener plant and a desalinization plant both takes water from the aquifer but through different geological formations, San Luis and San Andres, each one with different amount of water availability. A water softening plant with $66 \mathrm{l} / \mathrm{s}$ water production capacity but only extracts $14.4 \mathrm{l} / \mathrm{s}$ in which only $8.3 \mathrm{l} / \mathrm{s}$ reaches people located in the center, hilly and south part of the island; this plant takes water from the San Andres formation.

A desalination plant with $501 / \mathrm{s}$ water production capacity that extracts $42.4 \mathrm{l} / \mathrm{s}$ in which only $23.6 \mathrm{l} / \mathrm{s}$ reaches people located in the north and urban area of the island, and takes water from the San Luis formation. The contract established that each system will provides water to different sectors; desalinization water is given mostly to the touristic sector and the water from the softening plant is given mostly to the residents located in south-center and hilly parts of the island.

Distribution of water in the island is done by two methods: 1) the aqueduct; and 2) the water trucks which takes water also from the aquifer but without any preliminary water treatment. According to the Quality of Life Survey DANE in 2011, it reported an aqueduct access of $31.6 \%$, and only $22.7 \%$ for sewerage (DANE 2011; ORMET Archipelago, 2013), and a high imbalance between supply and demand for drinking water for the population (Guerrero, 2015).

According to climate change predictions, it is expected that the Archipelago is going to suffer a reduction of precipitation from $10 \%$ to $30 \%$ in the period 2071-2100 (Climate Change Third Communication, 2017). According to reports of the National University of Colombia (2010), the Archipelago has an average rainfall precipitation of $1973 \mathrm{~mm}$. The island has a dry season from January to April with $168 \mathrm{~mm}$ accumulated, and there is a wet season from June to November with $1509 \mathrm{~mm}$ accumulated. Historically, the dry seasons have been reported to turn into droughts, but only few scientists have confirmed that it has happened in the past or that it will happen in the future.

According to some historians, there were three historical episodes of drought in the Archipelago of San Andres, Providence and Santa Catalina. One occurred between 1928 and 1930 with $500 \mathrm{~mm}$ of rainfall; in 1959 with $558 \mathrm{~mm}$ of rainfall; and, again in 1986 with $239 \mathrm{~mm}$ of rainfall. As reported by Barriga-Bonilla (1985), the period from 1959 to1967 the island had in February through May a monthly average rainfall below $100 \mathrm{~mm}$. Based on the study by Asprey and Robbins (1953), there was a drought during these months, and the vegetation was harmfully affected harmfully on the island.

In 2014, the Colombian Institute of Hydrology, Meteorology and Environmental Studies (IDEAM) made a national call to use water rationally because there is a risk that the Niño Phenomenon in Colombia will affect precipitation and thereby the replenishment of the supply of water sources.

Then, the environmental corporation in San Andres Island, CORALINA, which is the most important environmental authority in the island, initiated a diagnostic examining possible changes in aquifer hydrology. They found a tendency of increased electrical conductivity, indicator of salt content, in multiple wells in both aquifers, San Andres and San Luis.

Therefore, they mandated suspending the operation in some wells, and in others, breaking up the pumping time. They also found that in 2013 precipitation was $1565 \mathrm{~mm}$ less than the normal 
$(1900 \mathrm{~mm})$, which evidences a reduction of precipitation of $17 \%$ with respect to the annual average. They concluded that the recharge of the aquifer in 2013 was lower than the normal by the start of the usual dry period of 2014 and received the impact of the Niño phenomena (Rojas, M. Guerrero, T. and Bent, O. (2014).

Additionally, the environmental corporation stated that the dry period in the island is from January until April, and analyzed and compared specifically the precipitation of the dry periods from 1986 to 2014 . They found reductions of precipitation of $30 \%$ in 2013 and 49\% in 2014.

This diagnostic provides insights about the initiation of drought in the island and the uncertainty that existed within local institutions about precipitation as the result of the lack of a warning system. Meanwhile, in June 2014, the IDEAM confirmed, with a 73\% probability, that in the second half of the year El Niño will begin. On August 11, 2014, through resolution 693, CORALINA activated a preventive alarm implementing stricter control measures in the exploitation of the water in the island which will remain in force until IDEAM officially indicates that the effects of the Niño phenomenon have ceased and the aquifers have recovered their conditions to normal.

In October 2015, the IDEAM declared that the EI Niño Phenomenon had reached severe conditions, and later, on July 13,2016 , reported conditions of neutrality. The National Corporation of Risk Management (UNDGR, Spanish acronym) in 2016 reported a deficit of $47.9 \mathrm{~mm}$ of precipitation during El Niño.

On April 2, 2016, a group of people who live in the Lynval-Cove neighborhood put up barricades, burned tires, shouted, and put up notices saying, "We need water." That was the first social road protest for the lack of water in the island. This resulted in 10 additional road protests spread throughout the south-center of the island, where some poor neighborhoods and mostly people from the ethnic-minority group live. The last protest occurred in June 10, 2016.

As a result, negotiations and agreements took place between each neighborhood and the local government. The areas affected were: Barkers Hill, Simpson Well, Perry Hill, Back Road, Atlántico, Buenos Aires, Vista Hermosa, Salsipuedes, Bar Costa Rica, Lynval, Cove, San Luis (Four Corner, Tom Hooker, and Elsy Bar), Corales, and Barack. Thus far, the drought has affected 14,000 people (Action Plan report, 2016).

On April 15th 2016, occurred the first water crises in the history of the island. The local Government, supported by the national government, declared a State of Public Calamity in the Archipelago, attributing the cause of the lack of water to the El Niño phenomenon. They explained that this phenomenon had adversely affected the population, who do not have sufficient water resources to meet the demand of inhabitants and tourists, and this in turn led to a water shortage, generating protest demonstrations (Decree No. 170, 2016). No shortages were reported by the touristic sector.

The immediate response was coordinated by the national and the local government, including the distribution of over $8,000,000$ liters of water to various neighborhoods over a period extending from April 3 to May 9. The government is implementing a long-term solution involving the purchase and operation of a desalination plant, the improvement of the water supply system, improvement of fire fighters' equipment to deal with the distribution of water, and also the implementation of controls on hotels with high rates of water consumption.

\section{METHODOLOGY}

Acknowledging the importance of the community voice, this paper describes and analyses how different segments and sectors framed the 2016 water crisis. During 15 days of fieldwork in August, 2016, 34 semistructured interviews were conducted: 21 interviews with residents in affected neighborhoods and 13 interviews with personnel officials.

Typically, interviews took about 30 minutes. The participants were at first purposively sampled and then snowball sampling was used, asking the interviewees if they would recommend anyone else to be interviewed, too. Participants were people from several neighborhoods, including Court House (2), Little Hill (1), Barkers Hill (3), Loma Lynval- Loma Cove (3), Elsy Bar (1), Buenos Aires - Atlantico (3), and Sagrada Familia (2). In total, 10 females, 11 males, and 12 people identified as Raizal, and nine who identified as nonRaizal were interviewed.

Officials were interviewed from the public services secretariat (1), the risk management office (2), the fire department (1), the civil defense office (2), the environmental corporation (2), the water public/private company (1), owners of the water truck companies (1) and a congressional representative (1). In total 11 females and 9 males. A general description of the participants and their role in the water management is included in order to allow a better understanding of the different perspectives:

1) Raizales: People identified as the indigenous ethnic group, characterized by their AngloPuritan/African heritage, Protestant religious tradition, and English mother tongue.

2) non Raizales, people identified as a Islanders (people who are from San Andres but came from 
the Colombian mainland during the 50's until the 90's, including their descendants);

3) Environmental organization: CORALINA is the local agency in charge of environmental action and natural resources management in the Archipelago;

4) Private water companies: Veolia, in charge of the production, sale, distribution of fresh water and the disposal of waste water in the island, excluding bottled water. Water truck companies extract and transport water to different sectors in the island;

5) Local government including firefighters, the risk management office, and the public services secretariat.

All data were collected and recorded in face-toface interviews with people affected; two semistructured interview guides were used: one for government officials and private company personnel, and the other for residents in the affected communities. The semi-structured interview contained sections that dealt with topics about water access, and perception and experience during the 2016 water crisis.

Considering the research question, the analysis centers on answers, comments, and expressions related to the water crisis and issues in the access of water in the island. In the data analysis, the researcher went from inductive to deductive analysis where were developed umbrella categories under which to organize specific themes. The interview transcripts were re-read and the codes and concepts were reconfigured or redefined if necessary. Manual coding was performed.

Overall, under the 'water crisis understanding' umbrella category, the institutional voices defined three themes: the crisis causes and characteristics, crisis experience, and effects. The 'people affected voices' defined three themes: ways in which they managed to get water, crisis causes and characteristics, and experience.

\section{THE INSTITUTIONAL VOICES IN A NATURAL WATER CRISIS}

During a crisis, it is a difficult task to achieve a collective understanding, specifically of the causes, characteristics, and effects of an evolving threat (Boin, Kuipers and Overiidt, 2013). This task is commonly called sensemaking.

Findings of the present study showed that the 2016 water crisis was framed by the institutional voices as a problem triggered mainly by technical and natural factors. It was characterized by conflicts, violence, misunderstandings, and political negotiations in which was necessary to act immediately. It was unexpected, uncertain, something new, and without preparation in advance. Officials perceive the Niño phenomenon and the drought as the trigger and the protests as the first sign or alarm of the water crisis.

Broadly, officials point out that the water problem in the island was a sum of multiple factors: 1) drought and Niño phenomenon, 2) the inefficiency of the private water company to produce and distribute, 3) mass tourism, 4) overpopulation, 5) lack of technology to use seawater to produce fresh water, 6) weakening of cultural water storage techniques, and 7) corruption. However, public officials point out multiple variables, the majority of which emphasize classic natural hazard types like drought as the main cause of the water crisis (Kuipers and Welsh, 2017).

Throughout the interviews, the majority of officials mention that the crisis was unexpected, violent, and demanded hard work. A firefighter who had to distribute water said "It was a marathon task; we could only sleep three hours a day." He explained that "We [risk management personnel] were not prepared," "This crisis took us by surprise." The government secretariat explained that "we did not have an emergency response protocol in place because this never happened before".

In order to illustrate the severity of the crisis officials repeatedly used words such as "conflicts" and "aggressions" against the government, the police, the water private company, and amongst the people. They indicate that the first big alarm of the crisis was the multiple community protests in which people put up barricades and burned tires.

A recurrent insight among public officials was that they "have never seen a protest or fights due to lack of water in the island." A firefighter said "it was really heartbreaking for me to see my people struggling for water." A government representative expressed that "the water crisis became a matter of public order," and it was necessary for the police to intervene.

Both institutions, the police and the government, created different negotiation tables in each neighborhood, trying to stop the protest. They explained that this process was very challenging and when they thought one protest was going to end, a new one cropped up in another neighborhood. There were approximately 11 protests in total.

On April 14, 2016, ten days after the first protest started, the government secretariat called an extraordinary risk management meeting. In this meeting the Risk Management Council, discussed the emergency and the necessity of national government support.

The scale of the crisis overstretched local coping mechanisms and required external assistance which they could have by declaring the island in a State of Public Calamity. In this meeting mainly participated 
institutions related to public order and water resources management, and community leaders were not invited. On April 15, the local Government, for the first time in its history, declared the State of Public Calamity, attributing the cause of the lack of water mainly to the Niño phenomenon (Decree No. 170, 2016).

Public officials explained in more detail what made this year different than others to instigate a crisis and why they did not see this crisis coming. Throughout the interviews, officials pointed out that this drought was the most severe, intense, longest, and most extensive in San Andres history. The civil defense personnel said this time was different because "this drought impacted more than a half of the island," "it grew and expanded silently," "the rain was very mild, it did not have the duration or the strength necessary to recharge the aquifer, allowing the people to collect enough water." The situation was framed as hard, the government secretariat points out that "people from different neighborhoods called multiple times to the radio and local institutions demanding water." There were reports of water theft by neighbors from households with rainwater stored in cisterns.

The environmental corporation representative said that since 2012 San Andres began to suffer a reduction of precipitation. He highlighted that there was a discrepancy between the information given by the Institute of Hydrology, Meteorology, and Environmental Studies (IDEAM) and the reality of the climate on the island. They explained that

"they [the Institute] turned on the alarms in 2014 when the corporation had already started to restrict water exploitation in 2013."

They clarified that the drought did not start in 2016, but rather may have begun in 2012 but did not show its impact until 2016. Wilhite (2002) and Peters (2012) explain that the precise onset of droughts is difficult to predict, making it difficult to prepare for them and to manage properly; this difficulty may increase with the uncertainties introduced by climate change.

Some of the water related institutions, like Veolia and the water truck companies, talked about the impacts they suffered during the crisis, showing themselves as also a victim and not only as responders during an emergency, justifying why they had difficulties in supplying water. They had to reduce the production of water dramatically.

Considering the increase in conductivity, a test for salt content, of the wells and low water tables, the environmental corporation restrained the water exploitation to the Duppy Gully water plant, which give water to the rural-center-hilly part of the island where mainly the Raizales are located. Water exploitation in the desalination plant was not restricted. The Veolia personnel explained that they five years ago extracted 35 liters per second of water and currently they extract 17 liters per second. An owner of a water truck company said that

"everything was chaotic, people called us constantly asking for water, but we only had a single truck and a single well with water, so people had to wait 20 days." They said, "we already have obligation to several hotels, so decisions were difficult."

Regarding that only $39 \%$ of the island had aqueduct service, crisis impacted people differently according to the source of water used. For instance, people who mainly get water from wells and rain water ran dry because of drought. That situation, accordingly to the majority of the institutions, was unknown. Actually, during the interviews it was noted that there is an unidentified water demand created by islanders who have not depended on the private water company during good rain years and became kind of water selfsufficient. The local government, who has the responsibility to provide emergency water did not know about this hidden demand (Peters, 2013). Meeting household water needs and not knowing if you have enough water resources to be prepared and response during periods of extreme low rainfall or localized droughts could become a mission impossible without this information.

People who get water from the aqueduct spent more than 47 days without water and when they received it, it was only for less than two hours. This situation combined with the lack of rain and the inadequacy of the private water company that reduce water availability.

The situation was also unknown by the Risk Management officials, firefighters, and civil defense because Veolia did not report this situation in a timely manner. Veolia personnel explained that the agreement signed between the company and the local government established a differentiated water supply frequency. The distribution was 24 hours a day for the north part of the island and in some San Luis sectors where the tourism infrastructure is located, (Proactiva, 2005) and only once every 20 days for the other sectors of the island, where mostly the poor and the Raizales are located. This water distribution and frequency was established by the superintendent of public services, local and national water experts, and the local government.

Adding to the above mentioned, another recurrent topic named by the officials, mainly by Veolia personnel, was that people were confused about the water system in the island. This confusion or 
disinformation has created tension and anger against the water company, motivating people to protest.

\begin{abstract}
"They do not know how the water is distributed in the island, they believe we [Veolia] take water from the aquifer and send it to the tourists, but that is not true; we send desalinized water, that is more expensive, to the tourist and commerce part of the island, and the community receives water from the aquifers, from the Duppy Gully water plant."
\end{abstract}

In the water agreement it was established that each system will provide water to different sectors; desalinized water is given mostly to the touristic sector, hotels, and the water from the underground is given mostly to the islanders. The Veolia representative said, "We [Veolia] only follow our contract and we have not taken water from the aquifer to the touristic sector."

With that in mind, it is important to clarify that the desalinization plant does not take water directly from the sea; instead they extract water from the aquifer, too, but only in the occidental and plain part of the island where water is saltier.

The absence of water, being a necessary good for multiple uses, generates a series of demands leading to competition among sectors and individuals which becomes greater in the presence of increasing pressure factors like drought or economic interests like tourism. In times of water scarcity, hierarchizing is a common solution, and the criteria to decide who gets water first can cause additional complications. During the water crisis tourism activity was prioritized. Historical references confirm that water has been prioritized since 1953 to tourism (Mattos, 2004). Raizales, were slowly displaced to the south and high parts of the island, and isolated from the economic benefits of tourism (Avella; Abello and Mow, 2008).

An additional factor named by some public officials was that the drought coincided with the high season of tourism, and consequently the water demand increased considerably. Considering the economic stability of the island, the Government Secretariat said, "we tried to keep tourism away from the problem". Indeed, it seems that the touristic sector did not suffer from constant water shortages as their numbers were not reduced.

Finally, some interviewees made special comments about whose responsibility is this situation. Noting the deferral in sending water described by the government secretariat manager, they blame the water company and the agreement as one of the water problems in the island.

Apparently relying on the contract for justification, the private water company affirmed that the government made that decisions and they were not at fault. As Boin, Hart, and Kuipers (2017) stated, officials may defend themselves against seeming evidence of their incompetence and "they must establish beyond doubt that they cannot be held responsible for the occurrence or escalation of a crisis."

In this sense, conversations with public officials in some cases resulted into the blame game. For instance, the Government Secretariat and the private water company blame each other.

\section{THE PEOPLE'S VOICES IN A SOCIAL WATER CRISIS}

Participants explained that they can have access to water by combining five complementary water sources: drawing water from wells, rainwater, aqueduct or pipe water, bottled water, and water trucks. All participants buy bottled water and also highly depend on rainwater. Having multiple water sources could be an advantage; Wilhite (2002) mentioned that the diversification of water sources is a key aspect in managing vulnerability to drought, as different sources may be affected differently by rainfall variability.

However, according to the participants there was a collapse in all water sources. Indeed, there are different ways to have access but there are basically two main water sources, the rain and the aquifer which are intrinsically related to each other.

During the water crisis, participants explained that it did not rain for more than sixth months, the wells and cisterns were dry, and the water company told them did not have enough water. In general, interviewees said they did not receive pipe-water from one to four months.

Although some houses were connected to the aqueduct, water does not necessarily flow down the pipes because the pressure was extremely weak. Some participants reported that "the water only flows for two hours every fifteen days", but during the water crisis they said that "water only flowed once per month or less", "I had to wait more than 15 days until my turn to finally get water"; another participant explains, "sometimes they [the water company] said Saturday morning, and I wait, but the water never came."

The water crisis brought out a variety of emotions as participants talked about the water crisis using words such as horrible, desperation, upset, distrust, and resignation. In the Sagrada Familia neighborhood, a participant claimed that there were multiple pregnant women and newborns in need of water, children could not go to school, and adults could not go to their jobs.

In Barkers Hill there were day care centers without water. Generally, all participants complained about the struggle to cook their food, to wash their clothes for their jobs and uniforms for school, the 
increment in the water prices to buy bottled water and water truck, and the economic burden for their family. They remarked that they have to use twice or three times the same water.

They said this time "we are determined to change this situation", and they believed that the only way the government will listen was by making protests; a participant from Loma-Cove said "the only language they listen is when you protest, when you become violent, when you become aggressive."

A woman from the Barkers Hill neighborhood said [metaphorically] "we had to burn half island to be listened to", this time "we were desperate." Interviewees claimed that the protests worked successfully to call the government's attention. Some protests were violent and others peaceful, as one participant from Court House said, "we need to fight for our rights." According to the participant's responses, the seeds of the water crisis has existed for several years, but this time they decided to do something about the situation.

The majority of the participants perceived that the water crisis was not directly related to natural causes. Some of them did not even identify the presence of drought in the island. A participant said "what is happening here is not part of nature, instead, it is the private water company, they put us in drought even if they have the water."

A recurrent comment during the interviews was "there is no drought, you can find water in the island, the problem is that they [water company] do not distribute water properly." Participants emphasized that they can have a drought caused by Veolia and not a natural one, "they [Veolia] do not depend on rain water."

Even though participants do perceive drought as a reduction of precipitation, they believe that the water crisis was created by the water company who created drought conditions. When the researcher asked "what is a drought" they said "when there is not rain and not water from the pipe."

When participants shared their experience in the crisis they talked about the different ways in which they managed to get water. Most of them commonly buy from a water truck. Neighbors who knew each other or shared the same water problem met to discuss and agree to buy from a water truck together. Others had to buy water in small quantities from neighbors who have large cisterns.

They explained how these large cistern owners resell the water using hoses or small tanks. Some of them get access to groundwater through common wells, they remember how in the past they used to get water from the lagoon and old wells. They use their personal vehicles, mostly motorcycles, to transport the water.
Participants recognize that there are differences among them in the access to water and consequently in the impacts of the water crisis. For instance, a person who lived close to the street (where there is strong water pressure), connected to the aqueduct, and have a big cistern could have been one month or less without receiving water; people who highly depend on rain water, not connected to the aqueduct, or living in the hills, could have been three to four months without water.

Having access to water depended on seven key factors:

1) having a cistern and the size of it, "neighbors with water during the crisis were the ones who had big cisterns or good networking to get water before others."

2) social networking, participants explained the importance to having connections to buy in group a water truck, to ask a friend for water; for example, the majority of the participants had to wait in line to receive water, but to be the first in line you could possibly call a friend.

3) having transport, since participants needed frequently to transport bottles of water and small tanks with water.

4) having access to an aqueduct, being connected to assure at least to have water every 15 to 20 days.

5) the location, the majority people situated in the rural areas do not have an aqueduct, participants located close to the street have better water pressure and also have better access to receive water from the water trucks.

6) knowledge and historical relation with the island as they can know where the old wells are to get water. and

7) 7) the economic capacity, since the existing water during the crisis was mostly distributed by the water truck companies who considerably increased the price from approximately $\$ 80,000$ to $\$ 130,000$ Colombian pesos. An alternative, however, constructing a cistern, requires significant economic investment.

In general, participants frequently mentioned shortages, naming environmental, socio-economic, and institutional factors. Regarding environmental reasons, they talked about the increment in water demands due to increased population, deforestation (which directly affects the groundwater levels), water overuse, and water contamination.

Concerning socio-economic issues, they pointed out mass tourism and water injustices. Referring to institutional shortcomings, participants referenced the 
lack of planning and the inadequacy of the government and the water private company to produce, distribute, and allocate the water resources among different sectors.

Generally, the community-responders clearly say that the increase in number of residents and tourists is putting strong pressure on water resources, producing over-exploitation of water. They directly blame tourist activity, the private/public water company, and the government for supplying the water to the tourist enterprises and not to them.

This calls attention to the need for research concerning the water injustice issue in water management. Mostly all participants see the water situation as unjust, reporting unfairness in distribution, quality, stress-inducing infrequency, and price gouging.

Participants perceived inequalities when it comes to their access to water resources. The researcher listened multiple times to community-responders saying "why do some parts of the island have 24-hour access to water and others do not." Words frequently heard during the interviews were "unfair and unequal," which seems to express what they perceived was the root cause of the crisis.

They saw multiple times the water trucks taking water from their land (the aquifer), to give it to the tourist enterprises. They said "the water that is under my house (aquifer) is not for me but is for the tourists who come and take our resources and leave." In the same way, they blame the private water company for extracting water from their land and not giving it to them. Participants claimed they were treated as "second level."

An example of this is a quote from a participant who lives in La Loma sector: "The owners of the water are the black people, and people from San Andres are black; the white people who live down there (in the north and plain part) have water, and we, who live up here (the high hill parts of the island), the owners of the water, we do not have water."

The crisis exposed uneven impacts, vulnerabilities, and social inequities. There was always water in the hotels in the north part of the island where tourism and commerce are located. The most affected people were the ones who were located in the south and hilly parts of the island, people who depend mainly on rainwater, the same ones who are not connected to the aqueduct, and the ones who mainly part from the ethnic minority group the Raizales.

According to Belmar, McNamara, and Morrison, (2016), the worst impacts affect the poorest and most marginalized members of society first, and these inequities in access and control of water increase their vulnerability. Overall, the 2016 water crisis was framed as a complex problem where issues of justice were predominantly named.

\section{CONCLUSIONS}

Overall, the way interviewees talk about the "2016 water crisis" in San Andres island revealed weaknesses and injustices of the current water system, including frequency, production, coverage, and distribution. Also, it shows high dependency on rainwater harvesting and the aquifer, the lack of drought, The Niño phenomenon, and crisis preparedness, significant levels of uncertainty about drought, water supply and demand, and a general unawareness about how the water system in the island works.

Participants believed the crisis does not emerge from a single, distinct event; instead it comes from multiple factors (Austin, Grosso and O'Neil, 2017). Additionally, participants exposed the high levels of complexity that the water resources management system has, since multiple factors influenced the crisis; for instance, people get water in various ways, there are two different production systems to supply water to different sectors, there is a differential water distribution by sectors, there is an unknown touristic water demand, and there is an overlooked and disconnected participation of the water truck network that supplies water in both normal and difficult times. All the abovementioned affected the way a crisis response is directed and the way drought management should be planned in the island.

Public officials, from their perspective, explained that the 2016 water crisis was caused by the Niño phenomenon that induced drought conditions since approximately 2013. This reduced the precipitation and the aquifer water tables, that together with water extraction combined to create a domino effect which caused a reduction of water availability and an increment in salt water levels in multiples wells.

Therefore, there was a reduction in water exploitation; this, in turn, caused water shortages in the aqueduct and a reduction of water supply to sell from the water trucks. At the same time, people ran out of water because their cistern and wells ran dry, and the aqueduct did not deliver water according to the agreement (every 20 days).

While all of this was happening, in the north part of the island tourism and commerce was only slightly affected. Following the government instructions and the water agreement, the touristic sector was affected as little as possible. The prioritization of political and economic factors over water management resulted in the distribution of water before and during the crisis being in inequitable shares between tourists and locals. Indeed, it has been noted that the allocation of water in San Andres to tourism is a conflict-ridden process.

Public officials frame the crisis as a problem triggered mainly by technical and natural issues; 
characterized by conflicts, violence, disinformation, and negotiations. Officials perceive the Niño-induced drought as the trigger of the crisis and the protests as the first sign or alarm of the water crisis. In this sense, crisis solutions were directed to technical aspects, ignoring social factors.

Overall, the water crisis, from an organizational point of view, showed the four interrelated features named by Quarantelly (1993) and Stern (2009): It has a threat, it was unexpected, it was something new, with not past experience, not early warnings, and without preparation in advance, officials, for instance, did not know the rain harvesting demand and the time of drought onset; in consequence, it was a crisis with significant levels of uncertainty.

The water crisis was framed differently by the people affected. They framed the crisis as a longlasting problem related to tourism activity, where social issues like justice were predominantly named. People explained how the cause of the crisis was more social than natural. The focus was directed to the unequal distribution of water where tourism was the main beneficiary. According to affected people, the government and private water company were the main actors responsible for this crisis and they had the power to end it. People connected to the aqueduct said the crisis was caused by a social-drought, in other words, a drought caused by the inadequacy of the private water company to produce, distribute, and allocate water resources among different sectors within the island.

Tourism is seen by the majority of people affected in a negative way. They believe the crisis only affects the community and did not represent any threat to the tourism industry. Indeed, the rapid and unplanned growth of tourism has contributed with water overexploitation, and the priority in water distribution and frequency by the private water company and the government has undermined the water access in the island. In this context, the power to define who will have access to or control over and who will be excluded from access to water leads to structural conditions of inequality and injustice in the access to water (Castro 2007).

The community believed that drought occurs because of the private water company who wants to make more profit by sending water to the touristic sector. They described the crisis with a variety of emotions like desperation, upset, anger, and distrust, which instigated multiple protests and consequently generated the crisis.

During the crisis there was high level of politics involved where people tried to show how strongly they felt about the lack of water and tried to influence decision makers; also, they became involved in pressure groups trying to change the island's water policy. Petitions and negotiations between public officials and community leaders were the main strategy to "end" the multiple protests.

This research revealed that the water crisis is far from being perceived in a homogeneous way among people affected and public officials. There is a necessity to reconcile community and institutional views for an adequate management. It is fundamental to recognize that voices of people affected are needed to be listen in order to understand the complexity of the water crisis.

It is necessary to implement an effective participatory process to engage the community in the water production, distribution, and decision-making in the island. Stakeholder participation is justified also on the basis that it is a means of realizing social justice. Also, local institutions need to combine different knowledge forms, like scientific and traditional knowledge (Raizal water-culture), taking the limitations of each one and reinforcing the strengths of all of them (Kelman, 2010).

An additional point is what to watch for before a new water crisis happens? This research exposed the importance of recognizing "red flags" and understanding why public officials could not see the water crisis coming (Boint, Hart, and Kuipers, 2017). Throughout the interviews, officials pointed out information necessary to take into account and monitor on a monthly basis that could become warning signs.

For instance, 1) information about past droughts in the island, which officials currently lack 2) Information about aqueduct service and coverage limitations by neighborhood or sector; 3 ) information about water distribution and frequency, when the private water company has a delay in supplying water they should reported immediately to the risk management office. 4) Information about the arrivals of tourists: tourism is increasing while the water system remains static, producing the same amount of water; 5) water storage capacity monitoring by neighborhood, so officials can know how long the community can be without rainwater; and 6) In real time, well water salt conductivity information and information on precipitation.

A crisis requires a broad understanding of the hazard. Sterns (2009) said that a crisis exhibits a great level of uncertainty regarding of the nature of the threat. In this case, the hazard is socio-natural and response requires knowledge of the water management system, of the political and socioeconomic networks who have the authority over the water resources, and of sociocultural factors of the exposed community. Knowledge about El Niño phenomenon and drought in relation to mass tourism is also essential. With that in mind, it is necessary that public officials move from concentrating in a specific discipline to a broad knowledge of factors, as McEntire and Davidson affirm, an interdisciplinary 
understanding of water management is required in order to effectively manage the crisis.

Finally, it is believed that this research can be useful in at least four ways: 1 ) it highlights the value for risk and water managers to combine the traditional hydro-climatological perspective with the analysis of social aspects, as a way of better understanding of what happens on the ground; 2) Water injustices play a fundamental role in the creation of crises, increasing vulnerability to natural hazards, and affecting the risk perception of drought. Therefore, it is highlighted the importance to add social justice as a new dimension of water crisis studies. 3 ) it leads to the identification of vulnerability factors that are relevant to water users but that often are not considered in drought vulnerability assessment (e.g. type of water source, social justice, externally imposed decisions from the government and the private water company deciding water allocation); 4) it strengthens the idea that governmental actors need to reach out to users and effectively communicate with them in order to enhance coordination and coherence of water crisis response. 5) Corroborate the necessity of pre-established principles, protocols, strict methods and regulations where planning and training are very important for appropriate response to water crises.

\section{REFERENCES}

Arjen Boin, Sanneke Kuipers \& Werner Overdijk (2013) Leadership in Times of Crisis: A Framework for Assessment, International Review of Public Administration, 18:1, 79-91, DOl: 10.1080/12294659.2013.10805241

Austin L., Grosso S., and O'Neil G. (2017). Slow-onset Crises: Review of Surge Practices: Transforming Surge Capacity Project Start Network.

Barriga-Bonilla, E. (1985). La Isla de San Andrés: Contribuciones al conocimiento de su ecología, flora, fauna y pesca. Bogotá: Universidad Nacional de Colombia.

Belmar, Y. N., McNamara, K. E., \& Morrison, T. H. (March 01, 2016). Water security in small island developing states: the limited utility of evolving governance paradigms. Wiley Interdisciplinary Reviews: Water, 3 , 2, 181-193.

Blaikie, P. M. (1994). At risk: Natural hazards, people's vulnerability, and disasters. London: Routledge.

Campbell, D., Barker, D., \& McGregor, D. (January 01, 2011). Dealing with drought: Small farmers and environmental hazards in southern St. Elizabeth, Jamaica. Applied Geography, 31, 1, 146-158.

Cashman A. (2013). Water security and services in the Caribbean. Technical note. No. IDB-TN 514. InterAmerica Development Bank. Environmental safeguard Unit.

Castro, J. (2007). Water governance in the Twentieth-First Century. Ambiente y sociedades. Campinas v.1, n.2. p. $97-118$
Coralina, Invemar (2014). Evaluación de la vulnerabilidad por ascenso en el nivel del mar (ANM) y propuesta de lineamientos de adaptación en las islas de San Andrés Providencia y Santa Catalina. Código: SAI-VA-003. Informe técnico final. Convenio Interadministrativo de asociación No. 003 de 2013. Santa Marta. 387 p.

Durieux F. Antunes M. \& Amaral S. (2010). Gestão de Riscos e Desastres Naturais no Turismo: um estudo do município de Blumenau/SC. Turismo em Analise, Vol. 21, n. 3. Retrieved from: http://www.each.usp.br/turismo/publicacoesdeturismo/ ref.php?id=3704

Fothergill, A., Maestas, E. G. M., \& Darlington, J. A. D. R. (1999). Race, Ethnicity and Disasters in the United States: A Review of the Literature. Disasters, 23, 2, 156-173.

Gamble D., and Curtis S. (2008). "Caribbean precipitation: review, model and prospect." Geography Compass 8 (4): 221-234.

Guerrero T. (2015). Cambio climático y gestión del recurso hídrico en la isla de San Andrés, Reserva de la Biosfera Seaflower. Actas... Presentación en el Centro de Pensamiento del Gran Caribe. San Andrés islaColombia

Howard S. (2015) Turismo Sostenible en el Gran Caribe.-. Conferencia de Centro de Pensamiento del Gran Caribe. San Andrés islas.

James, J. (2013). Tourism as an economic development strategy: the case of the islands of San Andres and Providencia. Revista cuadernos del Caribe, Vol. 16 No. $1,37-55$

James, J. (2015). La sostenibilidad del Turismo en el Archipiélago de San Andrés, Providencia y Santa Catalina. Conferencia de Centro de Pensamiento del Gran Caribe. San Andrés isla.

Kelman, I. (2010). Hearing local voices from Small Island Developing States for climate change. Local Environment, $\quad 15, \quad 7, \quad 605-619$. DOl: 10.1080/13549839.2010.498812

Mearns, R., \& Norton, A. (Eds.). (2010). Social dimensions of climate change: equity and vulnerability in a warming world. World Bank Publications

Mow, J. M., Taylor, E., Howard, M., Baine, M., Connolly, E., \& Chiquillo, M. (2007). Collaborative planning and management of the San Andres Archipelago's coastal and marine resources: A short communication on the evolution of the Seaflower marine protected area. Ocean and Coastal Management, 50, 3, 209-222.

ORMET - Estudio de Perfiles Ocupacionales del Sector del Turismo Archipielago de San Andres, Providencia y Santa Catalina (2015). Programa de las Naciones Unidas para el Desarrollo-PNUD (Ed.). Bogota

Gobierno Departamental (2010). Plan Departamental para el Manejo Empresarial de los Servicios de Agua y Saneamiento (PDA): Departamento de San Andrés / Viceministerio de Agua y Saneamiento (Ed.). Bogotá: Ministerio de Ambiente, Vivienda y Desarrollo Territorial, $20 \mathrm{p}$.

Quarantelli, E. L. (1993). Community Crises: An Exploratory Comparison of the Characteristics and Consequences 
of Disasters and Riots. Journal of Contingencies and Crisis Management, 1, 2, 67-78.

Smith, K. (2013). Environmental hazards: Assessing risk and reducing disaster. London: Routledge Taylor \& Francis Group.

Stern, E. (2009). Crisis Navigation: Lessons from History for the Crisis Manager in Chief. Governance, 22, 2, 189202

Stern, E. (2013). Preparing: The sixth task of crisis leadership. Journal of Leadership Studies, 7, 3, 51-56. Doi.org/10.1080/13549839.2010.498812

Tompkins E., Nicholson-Cole S., Hurlston Lisa-Ann., Boyd E., Brooks G., Clarke J. (2005). Surviving climate change in small islands- A guidebook. Tyndall Centre for Climate Change Research, Norwich, UK

Trottier, J. (2008). Water crises: political construction or physical reality?Contemporary Politics, 14, 2, 197-214.

UNWTO World Tourism Organization (2003). Djerba declaration on tourism and climate change. Djerba, Tunisia.

Vandermarker A. (2012). Water and Environmental Justice. A twenty-first century US water policy. Christian-Smith, J., Gleick, P. H., \& Cooley, H. Oxford: Oxford University Press.

Wilhite, D. (2000). Drought as a Natural Hazard: Concepts and Definitions. Chapter 1, in D.A. Wilhite (ed.), Drought: A Global Assessment, Natural Hazards and Disasters Series, Routledge Publishers, U.K
Gonzalez T, Urquijo J., Blauhut V. (2016). Learning from experience: a systematic review of assessments of vulnerability to drought. Nat Hazards 80: 951-973, Springer Science, Dordrecht.

Rojas, M. Guerrero, T. and Bent, O. (2014). Diagnostico actual del recurso hídrico subterráneo frente a la alerta de Fenómeno del Niño para 2015. Reporte Técnico. CORALINA. San Andrés islas.

Rocha M. \& Mattedi M. (2016). Tourism and Disaster: the case of floods and landslides in the tourist destination and Costa Verde e Mar - Santa Catarina (Brazil). Turismo \& sociedade, Vol. 9, n. 2, p. 1-23. Retrieved from:

http://www.each.usp.br/turismo/publicacoesdeturismo/ ref.php?id=1599

\section{Acknowledgements}

Thanks to the University of Colorado, Natural Hazards Center through its Quick Response Grant Program, this study was funded, in part, by a grant from this University, grant number CMMI1030670. Thanks to the University of Delaware and the Disaster Research Center, specially thanks to Director Tricia Wachtendorf for valuable discussion and advice. Thanks to my friend, Professor Michael Brook, for his useful comments. 